\title{
PEMBINAAN DAN PENGAWASAN DINAS KESEHATAN TERHADAP KUALITAS DEPOT AIR MINUM ISI ULANG DI KABUPATEN SIMEULUE TAHUN 2018
}

\author{
Muhammad Iqbal, Ayi Darmana, Darwin Syamsul \\ Peminatan Kebijakan dan Manajemen Pelayanan Kesehatan, Program Studi S2 Kesehatan Masyarakat \\ Institut Kesehatan Helvetia Medan \\ Email : m.iqbal.rush75@gmail.com
}

\begin{abstract}
Track Record Article

Diterima : 15 Mei 2019 Dipublikasi: 25 Juni 2019

To establish a drinking water depot business, entrepreneurs are required to follow the conditions set by the government. Based on an initial survey of 85 water depots in Simeulue District, only 27 depots met the requirements for healthy drinking water, but as many as 35 depots did not meet the applicable provisions. The purpose of this study is to find out the guidance and supervision of the Health Office on the Quality of Refill Drinking Water Depots. The research design used in this study was Cross Sectional. The population in this study was 65 depots of drinking water and samples taken by total sampling were 65 depots of drinking water. Data collection methods are primary data and secondary data. Data analysis used is binary logistic regression test. The results showed that coaching had a sig-p value of $.004<.05$ and supervision had a sig-p value of $.001<.05$ meaning that coaching and supervision had a significant influence on the Quality of Refill Drinking Water Depots. Results The odds ratio also shows that coaching is the most dominant factor, where coaching has an influence on the quality of refill drinking water depots as much as 39 times compared to poor coaching. The conclusion in this study is the influence of guidance and supervision on the quality of refill drinking water depots in Simeulue Regency.
\end{abstract}

Keywords : Development, Supervision, Drinking Water Refills

\section{Abstrak}

Untuk mendirikan usaha depot air minum, para pengusaha diwajibkan mengikuti syarat-syarat yang telah ditetapkan pemerintah. Berdasarkan survei awal yang sebanyak 85 depot air yang ada di Kabupaten Simeulue hanya 27 depot memenuhi ketentuan syarat air minum yang sehat, namun sebanyak 35 depot tidak memenuhi ketentuan yang berlaku. Tujuan penelitian ini untuk mengetahui pembinaan dan pengawasan Dinas Kesehatan terhadap Kualitas Depot Air Minum Isi Ulang. Desain penelitian yang digunakan dalam penelitian ini adalah Cross Sectional. Populasi dalam penelitian ini sebanyak 65 depot air minum dan sampel yang diambil dengan cara total sampling yaitu sebanyak 65 depot air minum. Metode pengumpulan data yaitu data primer dan data sekunder. Analisa data yang digunakan yaitu uji regresi binary logistic. Hasil penelitian menunjukkan bahwa pembinaan memiliki nilai sig- $p 0,004<0,05$ dan pengawasan memiliki nilai sig- $p$ 0,001 $<0,05$ artinya bahwa pembinaan dan pengawasan memiliki pengaruh secara signifikan terhadap Kualitas Depot Air Minum Isi Ulang. Hasil odds ratio juga menunjukkan bahwa pembinaan merupakan faktor yang paling dominan, dimana pembinaan memiliki pengaruh terhadap kualitas depot air minum isi ulang sebanyak 39 kali lipat di bandingkan pembinaan yang kurang baik. Kesimpulan dalam penelitian ini ada pengaruh pembinaan dan pengawasan terhadap kualitas depot air minum isi ulang di Kabupaten Simeulue.

Kata Kunci : Pembinaan, Pengawasan, Kualitas Depot Air Minum 


\section{Pendahuluan}

Air yang dapat diminum memiliki standar tertentu agar dapat dikatakan sebagai air layak konsumsi. Air minum merupakan kebutuhan manusia yang paling penting. Seperti diketahui, kadar air tubuh manusia mencapai 68 persen, dan untuk tetap hidup air dalam tubuh tersebut harus dipertahankan. Kebutuhan air minum setiap orang bervariasi dari 2,1 liter hingga 2,8 liter per hari, tergantung pada berat badan dan aktivitasnya. Namun agar tetap sehat air minum harus memnuhi persyaratan fisik, kimia, maupun bakteriologis (Siregar WD, 2012).

Menurut World Health Organization (WHO) tahun 2017, salah satu target MDG adalah untuk mengurangi setengah dari proporsi populasi yang tidak memiliki akses pasokan air minum pada tahun 2015. Sementara target MDG ini terpenuhi, hari ini masih ada sekitar 1,8 miliar orang menggunakan air yang tidak aman dari segi kontaminasi mikroba dan lebih dari 663 juta orang hidup tanpa peningkatan pasokan air di dekat rumah (Pérez and Brown, 2017).

Data dari Statistik Kesejahteraan Rakyat tahun 2017, Badan Pusat Statistik secara nasional menunjukkan sumber air utama yang paling banyak digunakan rumah tangga untuk minum adalah air kemasan $(35,15 \%)$, sumur terlindung $(18,69 \%)$, dan sumur bor/pompa (15,60\%), sebesar $47,68 \%$ rumah tangga di Indonesia memperoleh air minum dengan cara membeli. Sedangkan untuk memasak, mandi, mencuci, dan lain-lain sumber air utama yang digunakan yaitu sumur terlindung/tak terlindung (33,13\%), sumur bor/pompa (31,08\%), dan ledeng (18,27\%) sedangkan sumber air utama yang digunakan rumah tangga untuk mandi, mencuci, dll, adalah air dari sumur terlindung/tak terlindung dan sumur bor/pompa sebesar (28,85\%) (Kemenkes, 2018).

Data yang dikeluarkan oleh Direktorat Jenderal Kesehatan Masyarakat pada tahun 2018 yaitu secara nasional pada tahun 2017 terdapat 20.844 jumlah sarana air minum yang beresiko rendah dan sedang, 22,76\% (4.754) diantaranya diambil sampel airnya sebagai pelaksanaan pengawasan sarana air minum, hasil ini masih belum mencapai target Renstra Kementerian Kesehatan tahun 2017 yaitu 40\% sarana air minum yang dilakukan pengawasan. Terdapat 10 (sepuluh) provinsi sudah memenuhi target Renstra Kemenkes tahun
2017 dengan memperoleh hasil lebih dari 40\% persentase sarana air minum yang diawasi diantaranya Papua, Papua Barat, DIY, Maluku Utara, Sumatera Selatan, Kep. Bangka Belitung, Riau, Kep. Riau, Banten, Aceh $(54,47 \%)$ dan Sumatera Barat. Sedangkan provinsi dengan persentase terendah diantaranya NTB $(0,41 \%)$, dan Bali $(5,26 \%)$, terdapat satu provinsi yang belum memiliki data pelaksanaan pengawasan air minum yaitu provinsi Maluku (Kemenkes, 2018).

Gambaran persentase sarana air minum yang dilakukan pengawasan tahun 2017 sangat berbeda dengan 2 tahun sebelumnya. Pada tahun 2015, capaian nasional sebesar 43,58\% (101.972) sarana air minum yang diawasi dari jumlah sarana air minum sebesar 234.002 sarana dan angka ini telah mencapai target Renstra Kementerian Kesehatan tahun 2015 yaitu 30\% sarana air minum yang dilakukan pengawasan. Pada tahun 2015, pengawasan yang dilakukan hanya pengawasan secara fisik pada bangunan sarana air minum dengan menggunakan metode Inspeksi Kesehatan Lingkungan (IKL). Padahal seharusnya pengawasan dilakukan sampai pada pengambilan sampel air. Hal tersebut dikarenakan keterbatasan sumber daya di daerah untuk melakukan pemeriksaan sampel air. Sedangkan pada tahun 2016, pengawasan coba ditingkatkan pada pengambilan sampel air, pada sarana air minum yang membutuhkan jumlah sampel yang tidak terlalu banyak yaitu DAM (Depot Air Minum). Adapun DAM berjumlah 32.578 sarana dan terdapat 16,02\% (5.218 sarana) yang dilaksanakan inspeksi kesehatan lingkungan dan pengambilan sampel air. Pada tahun 2017 pengawasan dilakukan pada seluruh jenis sarana, dimana tahapan diawali dengan inspeksi kesehatan lingkungan. Sarana air minum yang masuk kategori resiko rendah dan sedang berdasarkan inspeksi kesehatan lingkungan dilakukan pengambilan sampel air (Kemenkes, 2018).

Dinas Kesehatan Kabupaten Simeulue pada tahun 2015 Dinas Kesehatan melaksanakan beberapa kegiatan Kesehatan Lingkungan seperti monitoring kualitas sarana air bersih yaitu monitoring dan pengawasan kualitas air mineral isi ulang dan inspeksi sanitasi sarana air bersih dan air minum dengan menggunakan water test kit sedangkan uji laboratorium belum dilaksanakan disebabkan alat dan sumber daya yang ada belum memadai dan mencukupi. Jumlah 
keluarga yang memiliki akses air bersih masih sangat minim. Dari hasil pengumpulan data melalui laporan bulanan masing-masing Puskesmas penggunaan air bersih pada setiap keluarga yang paling tertinggi adalah sumur gali sebanyak 19,91\%, Sumur Bor sebanyak $18,08 \%$, PAM sebanyak $14,4 \%$, mata air terlindung sebanyak $12.65 \%$ dan penampungan air hujan sebanyak 6,99\%, sedangkan terminal air sebanyak 1,06\% (Dinkes Simeulue, 2015).

Hal tersebut menjelaskan bahwa tidak semua air yang ada di bumi dapat dimanfaatkan oleh manusia untuk kebutuhan hidupnya. yang tertuang dalam UndangUndang Dasar Negara Republik Indonesia Tahun 1945 Pasal 33 ayat (3) yang menyebutkan bahwa, "Bumi air dan kekayaan alam yang terkandung di dalamnya dikuasai oleh Negara dan dipergunakan untuk sebesarbesarnya kemakmuran rakyat". (Akhadi, 2014) Seiring dengan meningkatnya aktivitas manusia menyebabkan kebutuhan akan air minum juga meningkat sehingga berbagai sarana penyediaan air minum juga jumlahnya semakin meningkat dengan pesat (Purba, 2015). Berdasarkan Peraturan Menteri Kesehatan RI Nomor 43 Tahun 2014, setiap Depot Air Minum wajib menjamin air minum yang dihasilkan memenuhi standar baku mutu atau persyaratan kualitas air minum sesuai ketentuan peraturan perundang-undangan dan memenuhi persyaratan higiene sanitasi dalam pengelolaan air minum (Menteri Kesehatan, 2014).

Air minum isi ulang merupakan suatu jawaban atas kebutuhan sebagian masyarakat di perkotaan. Sekitar tahun 1999, mulai merebak peluang usaha yang umumnya disebut sebagai Depot Air Isi Ulang (Pitoyo, 2005). Depot air minum adalah usaha industri yang melakukan proses pengolahan air baku. Depot Air Minum Isi Ulang menjadi air minum dan menjual langsung kepada pembeli (Jawetz, Melnick and Adelberg's, 2010).

Air minum yang dihasilkan DAMIU yang tidak memenuhi syarat fisik, mikrobiologis, kimiawi, dan radioaktif sesuai dengan ketentuan dalam Peraturan Menteri Kesehatan Republik Indonesia Nomor 492 Tahun 2010 dapat menyebabkan gangguan kesehatan seperti penyakit diare (Permenkes RI, 2010). Dari uraian tersebut jelas bahwa untuk melakukan usaha dibidang sumber daya air harus memiliki izin dari pemerintah atau pemerintah daerah yang bersangkutan tidak terkecuali untuk usaha air minum yang belakangan ini berkembang pesat. Seperti halnya usaha depot air minum. Untuk depot air minum sendiri, izin yang harus dimiliki seperti Surat Izin Usaha (SIUP), Surat Izin Tempat Usaha (SITU), dan Tanda Daftar Perusahaan (TDP) (Prawiro, 2013).

Untuk mendirikan usaha depot air minum, para pengusaha diwajibkan mengikuti syarat-syarat yang telah ditetapkan pemerintah. Dalam Keputusan Menteri Perindustrian dan Perdagangan Republik Indonesia Nomor 651/MPP/Kep/10/2004 tentang Persyaratan Teknis Depot Air Minum Serta Perdaganganya, dimana sangat jelas disebutkan bahwa depot air minum harus memnuhi syarat-syarat yang berlaku, seperti syarat usaha, syarat air baku, proses pengelolaan, mesin/peralatan dan mutu air minum. Hal ini untuk mencegah adanya praktek-praktek curang dari para pengusaha yang dapat merugikan konsumen (Menteri Perindustrian dan Perdagangan, 2004).

Persyaratan dan pengawasan terhadap kualiutas air minum (air yang aman untuk dikonsumsi langsung) termasuk depot isi ulang air minum diatur dalam Peraturan Menteri Kesehatan Nomor 492/Menkes/Per/IV/2010 tentang Syarat-Syarat dan Pengawasan Terhadap Kualitas Air Minum, air minum itu selain harus memenuhi persyaratan fisik dan kimia, juga harus memenuhi persyaratan mikrobiologis. Air minum harus bebas dari bakteri pathogen (Permenkes RI, 2010).

Dalam hal, pengawasan yang dilakukan untuk menjamin kualitas dari air yang dihasilkan, dan untuk itu diperlukan bukti otentik yang dapat menjamin kualitas air yang dihasilkan. Sehingga para pengusaha yang sudah memenuhi standar kualitas air dan telah melakukan uji laboratorium akan mendapatkan sertifikat laik higiene yang dikeluarkan oleh Dinas Kesehatan. Sertifikat tersebut juga menjadi salah satu syarat bagi pengusaha dalam mengurus izin usahanya, tetapi tidak semua pengusaha depot air minum mau melaksanakan hal tersebut (Yendra, 2017).

Depot air minum yang ada di Kecamatan Simeulue Timur Kabupaten Simeulue beberapa di antaranya menjalankan usaha tanpa ada serifikat izin usaha diantaranya 35 depot tidak memenuhi ketentuan yang berlaku namun bebas 
melakukan usahanya dimana depot tersebut tidak pernah melakukan pemeriksaan mikrobiologis serta 18 depot memiliki status pemeriksaan mikrobiologis yang sudah kadaluarsa. Beberapa pengusaha tidak melakukan uji laboratorium dan tidak mengetahui arti penting dari pengujian kualitas air yang mereka kelola. Hal ini jelas dapat menimbulkan masalah dikemudian hari.

Menurut ketetapan Qanun Bupati Simeulue No. 10 Tahun 2016, menjelaskan bahwa depot air minum yang beroperasi dan belum memenuhi persyaratan sebagaimana dimaksud dalam Qanun ini wajib menyesuaikan dengan Qanun ini dalam jangka waktu paling lama 1 (satu) tahun terhitung sejak Qanun ini ditetapkan. Setiap usaha Depot Air Minum yang tidak memenuhi kewajiban sebagaimana diatur dalam Qanun ini dikenakan sanksi administratif (Bupati Simeulue Provinsi Aceh, 2016).

Berdasarkan survei awal yang dilakukan peneliti pada bulan Juli 2018 ditemukan depot air minum sebanyak 85 depot air yang ada di Kabupaten Simeulue hanya 27 depot memenuhi ketentuan syarat air minum yang sehat, namun sebanyak 35 depot tidak memenuhi ketentuan yang berlaku namun bebas melakukan usahanya dimana depot tersebut tidak pernah melakukan pemeriksaan mikrobiologis serta 18 depot memiliki status pemeriksaan mikrobiologis yang sudah kadaluarsa. Hal ini menunjukan kurangnya pembinaan dan pengawasan dari dinas yang terkait khusunya Dinas Kesehatan Kecamatan Simeulue Timur Kabupaten Simeulue.

Bertolak dari permasalahan ini maka perlu dibahas aspek pentingnya Pembinaan dan Pengawasan Dinas Kesehatan terhadap Kualitas Depot Air Minum Isi Ulang di Kabupaten Simeulue tahun 2018. Tujuan penelitian yaitu untuk mengetahui pembinaan dan pengawasan mempengaruhi Kualitas Depot Air Minum Isi Ulang di Kabupaten Simeulue tahun 2018.

\section{Metode}

Desain penelitian menggunakan motode Survei Analitik yaitu meneliti bagaimana dan mengapa fenomena terjadi yang kemudian menganalisa hubungan antara fenomena tersebut sehingga dapat diketahui sejauh mana faktor resiko berpengaruh terhadap suatu kejadian. Penelitian ini menggunakan pendekatan Cross Sectional yaitu mempelajari hubungan antara faktor-faktor resiko dengan kejadian dengan menggunakan metode observasi atau pengumpulan data dalam waktu yang bersamaan. (Menteri Kesehatan, 2014).

Penelitian ini dilakukan di Depot Air Minum yang ada di Wilayah Kerja Dinas Kesehatan Kabupaten Simeulue dan penelitian dilaksanakan pada bulan Juli tahun 2018 sampai dengan bulan Maret tahun 2019. Populasi pada penelitian ini adalah seluruh Depot Air Minum Isi Ulang yang ada di Dinas Kesehatan Kabupaten Simeulue yaitu sebanyak 65 depot dan teknik pengambilan sampel dalam penelitian ini adalah total Sampling yaitu pengambilan sampel dari seluruh total populasi dengan jumlah 65 depot air minum.

Analisis data yang digunakan yaitu analisis multivariat. Analisis Multivariat bertujuan untuk melihat kemaknaan korelasi antara variabel bebas (independent variable) dengan variabel terikat (dependent variable) di lokasi penelitian secara simultan dan sekaligus menentukan faktor-faktor yang lebih dominan berpengaruh. Uji statistik yang digunakan untuk analisis multivariat yaitu Regression Binary Logistic (Regresi Binari Logistik) pada batas kemaknaan 95\% dengan perhitungan statistik $\alpha=0,05$.

\section{Hasil}

Berdasarkan hasil penelitian dapat dilihat bahwa dari 65 responden, sebanyak 31 responden $(47,7 \%)$ menunjukkan pembinaan dalam kategori baik dan 34 responden (52,3\%) menunjukkan pembinaan dalam kategori kurang baik. dari 65 responden, sebanyak 27 responden $(41,5 \%)$ menunjukkan pengawasan dalam kategori baik dan 38 responden $(58,5 \%)$ menunjukkan pengawasan dalam kategori kurang baik. Selanjutnya dari 65 responden, sebanyak 25 responden (38,5\%) memiliki kualitas depot air minum yang baik dan 40 responden $(37,0 \%)$ memiliki kualitas depot air minum yang kurang baik (tabel 1)

Berdasarkan tabulasi silang tabel 2 antara pembinaan dengan kualitas depot air minum isi ulang, diketahui bahwa sebanyak dari 31 responden $(47,7 \%)$ yang menyatakan pembinaan dalam kategori baik, sebanyak 24 responden (36,9\%) memiliki kualitas depot air minum isi ulang yang baik dan sebanyak 7 responden $(10,8 \%)$ memiliki kualitas depot air minum isi ulang yang kurang baik. Selanjutnya dari 34 responden $(52,3 \%)$ yang menyatakan 
pembinaan dalam kategori kurang baik, sebanyak 1 responden $(1,5 \%)$ memiliki kualitas depot air minum isi ulang yang baik dan sebanyak 33 responden $(50,8 \%)$ memiliki kualitas depot air minum isi ulang yang kurang baik. Berdasarkan hasil uji chi-square memperlihatkan bahwa nilai signifikan probabilitas pembinaan adalah $p$-value $=0,000$ atau $<$ nilai- $\alpha=0,05$. Hal ini membuktikan pembinaan memiliki hubungan dengan kualitas depot air minum isi ulang di Kabupaten Simeulue tahun 2018.

Berdasarkan tabulasi silang antara pengawasan dengan kualitas depot air minum isi ulang, diketahui bahwa sebanyak dari 27 responden (41,5\%) yang menyatakan pengawasan dalam kategori baik, sebanyak 23 responden (35,4\%) memiliki kualitas depot air minum isi ulang yang baik dan sebanyak 4 responden $(6,2 \%)$ memiliki kualitas depot air minum isi ulang yang kurang baik. Selanjutnya dari 38 responden $(58,5 \%)$ yang menyatakan pengawasan dalam kategori kurang baik, sebanyak 2 responden $(3,1 \%)$ memiliki kualitas depot air minum isi ulang yang baik dan sebanyak 36 responden $(55,4 \%)$ memiliki kualitas depot air minum isi ulang yang kurang baik. Berdasarkan hasil uji chi-square memperlihatkan bahwa nilai signifikan probabilitas pengawasan adalah $p$-value $=$ 0,000 atau $<$ nilai- $\alpha=0,05$. Hal ini membuktikan pengawasan memiliki hubungan dengan kualitas depot air minum isi ulang di Kabupaten Simeulue tahun 2018.

Berdasarkan table 3 hasil uji yang dilakukan pada penelitian ini menggunakan $\alpha=$ 0,05 , variabel bebas (independent) yang mempunyai pengaruh secara signifikan dengan variabel terikat (dependent) adalah sebagai berikut :

1) Pembinaan memiliki nilai sig-p 0,004 < 0,05 artinya pembinaan memiliki pengaruh secara signifikan terhadap Kualitas Depot Air Minum Isi Ulang di Kabupaten Simeulue Tahun 2018.

2) Pengawasan memiliki nilai sig- $p$ 0,001 < 0,05 artinya pengawasan memiliki pengaruh secara signifikan terhadap Kualitas Depot Air Minum Isi Ulang di Kabupaten Simeulue Tahun 2018.

Hasil pengujian ini menunjukkan bahwa pembinaan dan pengawasan memiliki pengaruh yang signifikan terhadap kualitas depot air minum isi ulang. Pembinaan dan pengawasan merupakan faktor yang tidak bisa dipisahkan untuk meningkatkan kualitas depot air minum isi ulang menjadi kearah yang lebih baik dan memenuhi syarat kesehatan, dikarenakan pembinaan dan pengawasan yang baik maka akan menghasilkan kualitas depot air minum isi ulang yang baik pula.

\section{Pembahasan}

\subsection{Pengaruh Pembinaan Dinas Kesehatan terhadap Kualitas Depot Air Minum Isi Ulang}

Hasil penelitian menunjukkan bahwa variabel pembinaan memiliki nilai sig- $p 0,004<$ 0,05 artinya pembinaan memiliki pengaruh secara signifikan terhadap Kualitas Depot Air Minum Isi Ulang di Kabupaten Simeulue Tahun 2018. Selanjutnya nilai Odds Ratio dari variabel pembinaan memiliki nilai OR 39,084. Hasil ini menunjukkan bahwa pembinaan yang baik, memiliki pengaruh terhadap kualitas depot air minum isi ulang sebanyak 39 kali lipat di bandingkan pembinaan yang kurang baik. Nilai $\mathrm{B}=$ Logaritma Natural dari 39,084 $=3,666$. Oleh karena nilai B bernilai positif, maka pembinaan mempunyai pengaruh positif terhadap kualitas depot air minum isi ulang.

Menurut penelitian yang dilakukan oleh Ma'arif tahun 2017 tentang Analisis Kualitas Air Minum Isi Ulang di Kota Makassar, menunjukkan bahwa hasil pengujian parameter TDS, total coliform, dan e.coli, dari 20 sampel yang diuji, terdapat 12 depot yang tidak memenuhi syarat total coliform dan 4 depot untuk e.coli. Berdasarkan penilaian dari kuesioner dari 12 depot yang tidak memenuhi syarat, 11 depot termasuk kategori cukup, yang berarti masih kurang dalam melakukan pemeliharaan alat. Seiring dengan kemajuan teknologi dan semakin sibuknya aktifitas manusia, maka masyarakat cenderung memilih cara yang praktis untuk memenuhi kebutuhan air minum. Air minum isi ulang merupakan salah satu alternatif pemenuhan kebutuhan air minum masyarakat di Kota Makassar. Pencemaran air baku khususnya air tanah semakin meningkat sehingga tidak dapat digunakan sebagai sumber air minum. Namun, banyak yang belum mengetahui kualitas air minum isi ulang yang telah sesuai dengan standar kualitas air minum. Oleh karena itu, perlu dilakukan analisis kualitas air minum isi ulang di Kota Makassar (Ma'arif, Selintung and Bakri, 2017).

Darmawan mengemukakan dalam penelitiannya tahun 2017 tentang Evaluasi 
Pengendalian Kualitas Air Minum pada Depot Air Minum Isi Ulang di Kabupaten Sleman Yogyakarta, bahwa depot Air Minum harus melakukan pengawasan secara periodic terhadap mutu air baku, yang ditunjukkan dengan hasil uji laboratorium, seperti yang tercantum pada pasai 3 ayat 2, Keputusan Menteri Perindustrian dan Perdagangan Nomor 651/MPP/Kep/10/2004. Dalam ayat dijelaskan bahwa pengujian mutu air baku dilakukan minimal satu kali dalam tiga bulan untuk analisa coliform, dan dua kali dalam satu tahun untuk analisa kimia dan fisika secara lengkap (Darmawan, 2017).

Penelitian lain yang dilakukan oleh Ramadhana tahun 2017 tentan Tanggung Jawab Pelaku Usaha Depot Air dalam Penerapan Kualitas Standar Mutu Air Minum Isi Ulang Dikaitkan dengan Perlindungan Konsumen di Kota Banda Aceh, menunjukkan bahwa tanggung jawab pelaku usaha depot air minum isi ulang belum memenuhi persyaratan hygiene sanitasi air minum di antaranya ada beberapa perlengkapan dan peralatan yang digunakan seperti kran pengisian air minum, kran pengisian galon sudah berkarat, tendon air minum sering terbuka, lantai hanya dilapisi karpet sehingga tidak kedap air, bangunan terbuat dari kayu sehingga tidak mudah untuk dibersihkan. Bentuk kerugian yang diderita konsumen karena tidak adanya penerapan kualitas standar mutu air minum isi ulang mengalami keracunan bakteri sehingga menyebabkan diare, gejala tifus, pusing. Upaya yang telah dilakukan oleh Dinas Kesehatan Kota Banda Aceh seperti melakukan pengawasan, sosialisasi, dan pembinaan, namun pengawasan yang dilakukan belum maksimal sebagaimana dalam peraturan perundang-undangan seperti belum memberikan sanksi terhadap pelaku usaha yang belum memenuhi kualitas standar mutu, belum adanya data yang terpilah, belum adanya kerja sama yang bersinergi dengan Yayasan Perlindungan Konsumen Aceh (YAPKA), sehingga masih ditemukan pelaku usaha yang belum menerapkan kualitas standar mutu. Diharapkan kepada pelaku usaha depot air minum isi ulang di Kota Banda Aceh menyadari tanggung jawabnya karena akan menimbulkan resiko bagi konsumennya dan pelanggaran terhadap hal tersebut dikenakan sanksi dalam aturan yang berlaku, oleh karena itu perlu mengikuti berbagai bentuk pelatihan, sosialisasi, dan pembinaan (Ramadhana, 2017).

Keberadaan usaha depot air minum yang cukup berkembang dewasa ini, di satu sisi memiliki arti yang positif dalam penyediaan air minum terutama pada masyarakat perkotaan. Akan tetapi di sisi lain memiliki resiko terhadap kesehatan masyarakat jika tidak dikelola dengan baik. Hal ini mengingat bahwa air yang dijual pada depot air minum sangat rawan pencemaran karna factor lokasi, penyajian dan pewadahan yang dilakukan secara terbuka dengan menggunakan wadah botol air minum kemasan isi ulang, sehingga diperlukan upaya pembinaan dan pengawasan hygiene sanitasi yang memadai agar tidak berdampak buruk bagi kesehatan konsumen.

Namun sangat disayangkan sebagian dari usaha depot air minum tersebut tidak menjalankan usahanya sesuai dengan peraturan yang berlaku. Hal ini dibuktikan dengan hanya beberapa dari depot air minum yang melakukan pendaftaran laik hygiene di Dinas Kesehatan Kabupaten Simeulue. Sampai saat ini hanya sebagian kecil saja depot air minum yang melakukan pendaftaran. Hal ini berarti hanya beberapa depot di Kabupaten Simeulue yang telah memiliki sertifikat laik hygiene dan dapat terjamin kualitas airnya.

Menurut hasil penelitian dalam melakukan pembinaan dan pengawasaan terhadap kualitas air yang dihasilkan oleh depot air minum, tim pembinaan dan pengawasan kualitas air depot air minum menggunakan standar kualitas air minum yang sesuai dengan Keputusan Menteri Kesehatan Nomor 492 Tahun 2010 tentang syarat-syarat dan pengawasan Kualitas Air Minum. Pembinaan yang dilakukan oleh Dinas Kesehatan Kabupaten Simeulue dengan cara memberi himbauan terhadap pengusaha depot air minum isi ulang untuk melakukan tes laik hygiene setiap tahunnya dan melakukan pembersihan alat atau mesin depot air minum setiap enam bulan sekali. Namun faktanya pembinaan terhadap kualitas depot air minum isi ulang di Kabupaten Simeulue masih belum berjalan dengan baik, sehingga masih banyak depot air minum yang belum pernah dilakukan pembinaan dan menyebabkan kualitas depot air minum isi ulang di Kabupaten Simeulue masih diragukan kualitasnya seperti yang terkandung dalam Kepmenkes tentang syaratsyarat kualitas air minum isi ulang yang aman bagi kesehatan manusia. 


\subsection{Pengaruh Pengawasan Dinas Kesehatan terhadap Kualitas Depot Air Minum Isi Ulang}

Hasil penelitian menunjukkan bahwa variabel pengawasan memiliki nilai sig- $p$ 0,001 $<0,05$ artinya pengawasan memiliki pengaruh secara signifikan terhadap Kualitas Depot Air Minum Isi Ulang di Kabupaten Simeulue Tahun 2018. Selanjutnya nilai Odds Ratio dari variabel pengawasan memiliki nilai OR 38,681. Hasil ini menunjukkan bahwa pengawasan yang baik, memiliki pengaruh terhadap kualitas depot air minum isi ulang sebanyak 38 kali lipat di bandingkan pengawasan yang kurang baik. Nilai B = Logaritma Natural dari 38,681 = 3,655. Oleh karena nilai B bernilai positif, maka pengawasan mempunyai pengaruh positif terhadap kualitas depot air minum isi ulang.

Sejalan dengan penelitian Harvelina tahun 2015 tentang Pengawasan dan Pengendalian Kualitas Air di Kecamatan Tembilahan Kota, menunjukkan bahwa pengawasan dan Pengendalian Kualitas Air di Kecamatan Tembilahan Kota, yaitu menetapkan standar teknis dan standar administrasi, melakukan tindakan penilaian/evaluasi dan melakukan tindakan perbaikan sebagai berikut : pelaksanaan pengawasan dan pengendalian terhadap kuaitas air di Kecamatan Tembilahan Kota yang dilakukan oleh Dinas Kesehatan Kabupaten Indragiri Hilir dan petugas puskesmas dinilai belum maksimal dikarenakan pengawasan dan pengendalian yang dilakukan oleh Dinas Kesehatan dan petugas puskesmas tersebut tidak sesuai dengan standar yang telah ditetapkan dalam melakukan pengawasan dan pengendalian depot air minum isi ulang. Hal ini dapat dilihat dari masih banyaknya pengusaha depot air minum isi ulang yang jarang memeriksakan kualitas airnya dan enggan memperpanjang surat rekomendasi kesehatan (Harvelina, 2015).

Faktor-faktor yang mempengaruhi dalam pengawasan dan pengendalian kualitas air di Kecamatan Tembilahan Kota. Faktor internal yaitu kurangnya sumber daya manusia (SDM) yang dimiliki oleh Dinas Kesehatan dalam menjalankan pengawasan depot air minum isi ulang yaitu kurangnya petugas puskesmas atau petugas sanitasi, pelaksanaan kegiatan sosialisasi yang masih sangat kurang terhadap pengusaha depot air minum isi ulang, keterbatasan fasilitas penunjang pemeriksaan (labor) dan dana, serta belum disahkannya Peraturan Daerah (Perda) yang mengatur mengenai depot air minum isi ulang. Sedangkan faktor eksternal yaitu kurangnya kesadaran dari pemilik depot untuk memeriksakan kualitas air, memperpanjang surat rekomendasi kesehatan dan masih kurangnya pengetahuan dari pengusaha depot mengenai pengawasan dan pengendalian yang dilakukan oleh Dinas Kesehatan dan Puskesmas (Harvelina, 2015).

Menurut penelitian yang dilakukan oleh Saputra tahun 2017 tentang Pengawasan Terhadap Izin Usaha Depot Air Minum Isi Ulang di Kecamatan Kuranji Kota Padang, menunjukkan bahwa proses pemberian izin usaha dan pelaksanaan pengawasan terhadap izin usaha depot air minum isi ulang di Kecamatan Kuranji Kota Padang yang dilakukan oleh Dinas Kesehatan Kota Padang sudah sesuai dengan aturan yang ada, namun pengawasan tersebut belum merata karena hanya sekitar $70 \%$ depot air minum isi ulang yang terawasi. Itu semua terjadi karena Dinas Kesehatan Kota Padang terkendala dalam ketersediaan tenaga pengawas. Selain itu, pemberian sanksi yang diterapkan oleh Dinas Kesehatan Kota Padang juga belum maksimal. Untuk mengatasi hal tersebut, Dinas Kesehatan Kota Padang mengupayakan penambahan tenaga pengawas dan meningkatkan intensitas pengawasan. Untuk lebih efektifnya pelaksanaan pengawasan yang dilakukan oleh Dinas Kesehatan Kota Padang sebaiknya lebih merata dan mencakup semua depot air minum isi ulang yang ada sehingga menjamin kualitas air minum yang disediakan dan tidak menimbulkan gangguan kesehatan bagi yang mengkonsumsinya (Saputra, 2017).

Selanjutnya penelitian yang dilakukan

oleh Paputungan tahun 2018 tentang Pengawasan Dinas Kesehatan dalam Pengoperasian Depot Air Minumisi Ulang di Kecamatan Pinolosian Kabupaten Bolaang Mongondow Selatan, menunjukkan bahwa pengawasan Dinas Kesehatan dalam pengoperasian depot air minum isi ulang di Kecamatan Pinolosian Kabupaten Bolaang Mongodow Selatan yang di ketahui dari hasil penelitian belum maksimal. Karena masih adanya pengusaha depot air minum isi ulang yang beroperasi tanpa memiliki izin, kemudian tidak adanya sangsi tegas dari instansi terkait bagi para palaku usaha depot air minum isi ulang yang belum memiliki izin, serta kurangnya kesadaran dari pengusaha depot air 
minum untuk mengurus izin usaha dan juga terus berusaha meningkatkan mutu air yang di produksinya, karenanya berkesan para pengusaha kurang memperhatikan kualitas air serta izin usaha dan hanya mendahulukan keuntungan pribadi (Paputungan, 2018).

Kecenderungan masyarakat untuk mengkonsumsi air minum isi ulang menyebapkan usaha penyediaan air minum ini memerlukan pembinaan serta pengawasan dalam pengoperasiannya agar air minum yang di hasilkan selalu aman dan sehat untuk dikonsumsi. Pada pengoperasian usaha DAM ini berhubungan langsung dengan kesehatan masyarakat luas dan berkenaan hamper seluruh aspek kehidupan, maka dengan itu persyaratan kualitas air minum harus dipenuhi. Pengaturannya berdasarkan peraturan menteri kesehatan.

Menurut hasil penelitian pembinaan dan Pengawasan terhadap kualitas air pada depot air minum harus dilaksanakan oleh tim pembinaan dan pengawasan air isi ulang, sebagaimana diatur dala Keputusan Kepala Dinas Kesehatan Kabupaten Simeulue tentang Pembentukan Tim Pemeriksa tempat-tempat Umum, Institusi, Tempat Penyediaan dan Pengelolaan Makanan Minuman, Tempat Pengolahan dan Penyediaan Pestisida dan Air Bersih yaitu dengan melakukan pembinaan dan pengawasan terhadap saranasarana yang digunakan dalam usaha depot air minum tersebut. Di samping itu seharusnya pengawasan dilakukan secara intern oleh pemilik/penanggung jawab/operator depot air minum terhadap kualitas bakteriologis dan kimiawi air minum ataupun air baku dan juga oleh asosiasi depot air minum terhadap kualitas fisik bangunan dan instalasi depot air minum secara berkala setiap 6 (enam) bulan sekali dan melaporkan hasilnya ke Dinas Kesehatan Kabupaten Simeulue.

Untuk usaha depot air minum yang ada, selama ini lebih ditekankan kepada pembinaan yang dilakukan dengan sosialisasi tentang pentingnya melakukan uji laboratorium terhadap kualitas air untuk mendapatkan sertifikat laik hygiene. Untuk pengawasannya Dinas Kesehatan Kabupaten Simeulue berkoordinasi dengan petugas kesehatan yang ada di seluruh Puskesmas Kabupaten Simeulue untuk mengetahui apakah ada Kejadian Luar Biasa keracunan dan atau penyakit yang pernah terjadi akibat mengkonsumsi depot air minum yang ada di Wilayah Kabupaten Simeulue. Dari hasil penelitian dan fakta di lapangan diketahui bahwa pengawasan terhadap kualitas air pada depot air minum di Kabupaten Simeulue masih kurang optimal dan perlu ditingkatkan lagi.

Faktor penghambat dalam pengawasan kualitas depot air minum dari pihak pengusaha yaitu kurangnya kepedulian para pengusaha depot air minum terhadap pentingnya melakukan pendaftaran untuk mendapatkan sertifikat laik hygiene, tinggginya biaya dalam melakukan uji laboratorium. Sedangkan dari pihak petugas Kesehatan Kabupaten Simeulue sendiri dikatakan bahwa belum tersedianya alokasi dana untuk seksi penyehatan lingkungan dalam melakukan pengawasan serta belum adanya Peraturan Daerah yang mengatur tentang pengawasan kualitas air depot air minum sebagai dasar hukum dalam melakukan tindakan apabila terdapat pelanggaran yang dilakukan oleh pengusaha depot air minum yang selama ini menjalankan usahanya dan untuk memberikan kepastian serta jaminan hukum bagi para pengusaha dan masyarakat yang terlibat dalam usaha depot air minum.

\section{Kesimpulan dan Saran}

Kesimpulan dalam penelitian ini yaitu Pembinaan yang dilakukan pada depot air minum isi ulang di Kabupaten Simeulue masih dalam kategori kurang baik. Pengawasan yang dilakukan pada depot air minum isi ulang di Kabupaten Simeulue masih dalam kategori kurang baik. Kualitas depot air minum isi ulang di Kabupaten Simeulue masih kurang baik. Pembinaan memiliki pengaruh terhadap kualitas depot air minum isi ulang di Kabupaten Simeulue. Pengawasan memiliki pengaruh terhadap kualitas depot air minum isi ulang di Kabupaten Simeulue. Pembinaan merupakan faktor yang lebih dominan atau yang lebih besar pengaruhnya, dimana pembinaan yang baik memiliki pengaruh terhadap kualitas depot air minum isi ulang kearah yang lebih baik sebanyak 39 kali lipat, dibandingkan dengan pembinaan yang kurang baik.

Saran dalam penelitian ini antara lain : Sebaiknya intensitas pembinaan dan pengawasan terhadap kualitas air pada depot air minum yang ada di Kabupaten Simeulue yang dilakukan oleh petugas kesehatan perlu ditingkatkan, dan sebaiknya pemerintah Kabupaten Simeulue membuat suatu kebijakan berupa tanggung jawab penuh kepada petugas yang bersangkutan dalam melakukan 
pembinaan dan pengawasan, menyediakan anggaran yang cukup dan peralatan yang memadai untuk melakukan pembinaan kepada pengusaha depot, memberikan penghargaan bagi pengusaha depot yang memiliki kualitas depot air minum yang baik dan memberikan teguran serta sangsi ditarik izin usahanya dan penutupan usaha depot, bagi pengusaha depot yang melanggar syarat kualitas depot air minum isi ulang.. Sebaiknya dinas terkait yaitu Dinas Kesehatan Kabuapaten Simeulue memberikan usulan mengenai Rancangan Peraturan Daerah Kabuapaten Simeulue tentang Pengawasan Kualitas Air Pada Depot Air Minum kepada DPRD Kabuapaten Simeulue untuk menjamin kepastian hukum bagi usaha depot air minum yang melanggar syarat kesehatan serta memberikan perlindungan hukum bagi masyarakat pengkonsumsi air depot air minum tersebut jika terjadi pelanggaran yang mengakibatkan suatu penyakit atau keracunan serta adanya kejadian luar biasa.

\section{Daftar Pustaka}

Akhadi, M. (2014) Isu Lingkungan Hidup, Mewaspadai Dampak Kemajuan Teknologi dan Polusi Lingkungan Global Yang Mengancam Kehidupan. Jakarta: EGC.

Bupati Simeulue Provinsi Aceh (2016) 'Qanun Kabupaten Simeulue Nomor 10 Tahun 2016 Tentang Izin Usaha Depot Air Minum', pp. 1-10.

Darmawan, B. A. (2017) 'Evaluasi Pengendalian Kualitas Air Minum pada Depot Air Minum Isi Ulang di Kabupaten Sleman, Yogyakarta', Khazanah, 4(1), pp. 33-54. doi: 10.20885/khazanah.vol4.iss1.art4.

Dinkes Simeulue (2015) Profil Kesehatan Kabupaten Simeulue. Aceh: Dinas Kesehatan Kabupaten Simeulue.

Harvelina, W. (2015) 'Pengawasan dan Pengendalian Kualitas Air di Kecamatan Tembilahan Kota', JOM FISIP, 2(1), pp. 111.

Jawetz, Melnick and Adelberg's (2010) Medical Microbiology. 26th edn. New York: McGraw-Hill.

Kemenkes, R. I. (2018) Profil Kesehatan Indonesia Tahun 2017. Jakarta: Kementerian Kesehatan Republik Indonesia.

Ma'arif, M. N., Selintung, M. and Bakri, B. (2017) 'Analisis Kualitas Air Minum Isi Ulang di
Kota Makassar', Program Studi Teknik Lingkungan Jurusan Sipil Fakultas Teknik Universitas Hasanuddin, pp. 1-11.

Menteri Kesehatan (2014) 'PMK 34 Tahun 2014', 2008, p. 203.

Menteri Kesehatan. PMK 34 Tahun 2014.2014;2008;203.

Menteri Perindustrian dan Perdagangan (2004) Keputusan Menteri Perindustrian dan Perdagangan Republik Indonesia Nomor 651/Mpp/Kep/10/2004 tentang Persyaratan Teknis Depot Air Minum dan Perdagangannya Menteri Perindustrian dan Perdagangan Republik Indonesia. Jakarta.

Paputungan, R. (2018) 'Pengawasan Dinas Kesehatan dalam Pengoperasian Depot Air Minumisi Ulang di Kecamatan Pinolosian Kabupaten Bolaang Mongondow Selatan', pp. 1-7.

Pérez, M. del R. and Brown, J. (2017) 'WHO Guidelines for Drinking-Water Quality', WHO Chronicle, 38(3), pp. 1-56. doi: 10.1016/S1462-0758(00)00006-6.

Permenkes RI (2010) 'Persyaratan Kualitas Air Minum', (492).

Pitoyo, A. (2005) Dua Jam Anda Tahu Cara Memastikan Air yang Anda Minum Bukan Sumber Penyakit. Solo: Distribusi Terbuka.

Prawiro, R. H. (2013) Ekologi Lingkungan Pencemaran. Semarang: Satya Wacana.

Purba, I. G. (2015) 'Pengawasan terhadap Penyelenggaraan Depot Air Minum dalam Menjamin Kualitas Air Minum Isi Ulang', 6, pp. 63-73.

Ramadhana, S. (2017) 'Tanggung Jawab Pelaku Usaha Depot Air dalam Penerapan Kualitas Standar Mutu Air Minum Isi Ulang Dikaitkan dengan Perlindungan Konsumen di Kota Banda Aceh', 1(1), pp. 195-205.

Saputra, R. (2017) 'Pengawasan Terhadap Izin Usaha Depot Air Minum Isi Ulang di Kecamatan Kuranji Kota Padang', (6), pp. 67-72.

Siregar WD (2012) Analisis Kualitas Fisik,Biologi dan Kimia pada Air Minum dalam Kemasan Berbagai Merek yang dijual di kota Medan pada. Medan: Skripsi Universitas Sumatera Utara.

Yendra, R. (2017) 'Pembinaan dan Pengawasan Dinas Kesehatan terhadap Kualitas Depot Air Minum Isi Ulang di Kota Bandar Lampung', Fakultas Hukum Universitas Lampung, pp. 1-11. 
Tabel 1. Distribusi Frekuensi Berdasarkan Pembinaan, Pengawasan dan Kualitas Depot Air Minum Isi Ulang

\begin{tabular}{lcc}
\hline \multicolumn{1}{c}{ Pembinaan } & f & \% \\
\hline Pembinaan & 31 & 47,7 \\
Baik & 34 & 52,3 \\
Kurang Baik & & \\
Pengawasan & 27 & 41,5 \\
Baik & 38 & 58,5 \\
Kurang Baik & & \\
Kualitas Depot Air Minum Isi Ulang & 25 & 38,5 \\
Baik & 40 & 61,5 \\
Kurang Baik & & \\
\hline
\end{tabular}

Tabel 2. Tabulasi Silang antara Pembinaan dan Pengawasan terhadap Kualitas Depot Air Minum Isi Ulang

\begin{tabular}{|c|c|c|c|c|c|c|c|}
\hline \multirow{3}{*}{ Variabel } & \multicolumn{4}{|c|}{ Kualitas Depot Air Minum } & \multirow{2}{*}{\multicolumn{2}{|c|}{ Total }} & \multirow{3}{*}{ Sig-p } \\
\hline & \multicolumn{2}{|c|}{ Baik } & \multicolumn{2}{|c|}{ Kurang Baik } & & & \\
\hline & $\mathbf{f}$ & $\%$ & $\mathbf{F}$ & $\%$ & f & $\%$ & \\
\hline \multicolumn{8}{|l|}{ Pembinaan } \\
\hline Baik & 24 & 36,9 & 7 & 10,8 & 31 & 47,7 & 0,000 \\
\hline Kurang Baik & 1 & 1,5 & 33 & 50,8 & 34 & 52,3 & \\
\hline \multicolumn{8}{|l|}{ Pengawasan } \\
\hline Baik & 23 & 35,4 & 4 & 6,2 & 27 & 41,5 & 0,000 \\
\hline Kurang Baik & 2 & 3,1 & 36 & 55,4 & 38 & 58,5 & \\
\hline
\end{tabular}

Tabel 3. Uji Regresi Logistik

\begin{tabular}{lcrrrr}
\hline & \multirow{2}{*}{ B } & Sig. & \multirow{2}{*}{ Exp(B) } & \multicolumn{2}{c}{$\mathbf{9 5 , 0 \%}$ C.I. For EXP (B) } \\
\cline { 5 - 7 } & & & & \multicolumn{1}{c}{ Lower } & \multicolumn{1}{c}{ Upper } \\
\hline Pembinaan & 3,666 & 0,004 & 39,084 & 3,307 & 461,992 \\
Pengawasan & 3,655 & 0,001 & 38,681 & 4,893 & 305,803 \\
Constant & $-4,772$ & 0,000 & 0,008 & & \\
\hline
\end{tabular}

